\title{
Impact of Non-Interest Income on Financial Performance of Joint Venture Banks in Nepal
}

\author{
Ajay Kumar Shah ${ }^{1}$ Niraj Agarwal ${ }^{2}$ and Ram Kumar Phuyal ${ }^{3}$
}

\begin{abstract}
The research was conducted to identify the non-interest income variables that will likely affect the financial performance of the joint venture banks of Nepal. The main objective of the study is to analyze the prominence of non-interest income and its effect on financial performance of joint venture banks in Nepal. This study will help the banks to identify other sources of income of the bank and try to look at its impact on the overall profitability and risk intention. To measure the financial performance, the indicator of profitability i.e. returns on assets and return on equity are taken into consideration for the study as a dependent variable and assets size, letter of credit fee, guarantee income, remittance fee, dividend income, exchange income, service charge, and renewal fee as an independent variable. Both descriptive and inferential analyses were performed to capture the relationship. From the result analysis, it is observed that the non-interest income variables that would affect the financial performance of the joint venture banks. It is observed that not all variables have equal effect on the profitability as measure of financial performance, for joint ventures the factors like assets size, letter of credit fee, guarantee income, remittance fee, dividend income, exchange income, service charge, and renewal fee have a significant relationship with the measure of financial performance that is return on assets and return on equity. Apart from the interest income, there are lot of non-interest variables which leads to profitability so the banks looking to increase its profitability with lesser risk need to take these variables into consideration. Results indicate that banks need to keep the non-interest income variables into consideration at times for improving the financial performance of the joint venture banks.
\end{abstract}

Keywords: Financial performance, Non-interest income, Joint Venture Banks, Nepal

Mr. Shah is a Director of Ace Research Centre, Ace Institute of Management, Pokhara University.

Email: ajayshah@ace.edu.np

2 Mr. Agarwal is MBA graduate of Ace Institute of Management, Pokhara University

3 Dr. Phuyal is an Associate Professor of Centre for Economic Development and Administration, Tribhuvan University 


\section{Introduction}

The globalization and financial deregulation in the banking sector prolonged the banking activities produced different diversified products and services (Raluca, 2012). The concentration on banking services in the recent year has been shifted from traditional activities to nontraditional activities (Lozano-Vivas \& Pasiouras, 2010). The traditional role of commercial banks has centered on intermediation and the generation of net interest income through two core activities namely the collection of deposits on which banks pay interest and the issuing of loans for which they receive interest income (Craigwell \& Maxwell, 2005). Over the years, however, commercial banks have gradually expanded beyond their traditional role and sources of income to encompass more activities that generate the non-interest income (Sherene \& Tapper, 2010). The composition of noninterest income has also changed markedly during the last few years (Feldman \& Schmidt, 1999). Fee income has been mainstay so the dominant sources of noninterest income received by banks replacing the traditional mainstays of service charges and income from trust activities (Hoang, 2014).

The income that a bank receives other than interest income for such it may be the service charge penalty charges and to a much less extent, from assets sales and property leasing. The advantage of non-interest income to that of interest income is it is not affected by economic and financial market cycles and it is usually not controlled by law or regulation (Morris \& Regehr, 2014). Bank and creditor income are normally derived from fees. For example of such non-interest income included deposit and transaction fees, monthly account services charges, inactivity fees, check and deposit slip fees etc. institution charge fees that provide noninterest income as a way of generating revenue and ensuring liquidity in the event of increased default rates (Gichure, 2015).A joint venture is a business arrangement in which two or more parties agree to pool their resources for the purpose of accomplishing a specific task. This task can be a new project or any other business activity (Guo, 2015). In a joint venture, each of the participants is responsible for profits, losses and costs associated with it. According to the European law, the term joint venture is an elusive legal concept better defined under the rules of company law (Nichols, 1950). In Germany, joint venture is better represented as a combination of companies (Kallianiotis, 2013).

According to the analysis of Accenture; 158 global joint venture in the banking industry between the period of 2004 and 2012 (Timsina, 2015). There is a trend which follows an increment in the use of the public utilities and private parties involved in such action of joint venture. Joint ventures in Nepal are found to be operation well and the main cause for this is the increased public confidence towards such institutions and the capital base they have with such organizations. 
Non-interest income included all other income by the bank as a result of its on and off balance sheet activities and is becoming increasingly important as the category is income from fiduciary activities for example service charge on deposit accounts, other gains and fees from trading assets and liabilities item and other non-interest income and revenue from one time transactions such as sales of a real estate owned loans, premises and fixed assets (Saunders, 2014).

Most of the Nepalese commercial banks are enjoying around half of its net income from nontraditional activities based on sale of assets, dividend income, letter of credit, guarantee commission, remittance fee, exchange income, service charge and renewal fee (Nepal, 2015). On one hand where development of the bank and such institution plays a vital role for the economic development of the nation meanwhile on the other hand if one of such organization is not able to survive then it creates a scenario of disaster in the whole economy. In fact, bank is that business which is carried out by people's money and they should bear less risk Rai et al. (n.d.). In this verge, it raises some questions such as how the bank's internal non-interest income variables such as LC fee, guarantee income, remittance fee, renewal fee, service charge, $\mathrm{p} / \mathrm{l}$ of sale of assets, exchange income and dividend income are related to the profitability of bank? Do the variables of non-interest income significantly affect the financial performance of the bank? To answer these questions an analysis of the present balance sheet of the JV banks in Nepal need to be done. Such analysis may become an exemplary lesson to existing as well as new JV banks. Therefore, it is always essential to know the financial vulnerability of such banks. The changes in the interest rates and the increasing trend of default are making banks vulnerable to risk of bankruptcy. Therefore, the main objective of the study is to analyze the status of non-interest income and its effect on financial performance of the joint venture banks. Further, this study aims (i) to identify the position of profitability of the joint venture banks and sources of their income, (ii) to examine the relationship between the various non-interest income sources and bank performance and (iii) to analyze the effect of the selected non-interest income variables with financial performance of the joint venture banks of Nepal. It is believed that the outcome of this study helps banks to identify other sources of income of the bank and try to look at its impact on the overall profitability and risk intensity of such institution.

There are stakeholders in the bank having their own interest and desire and the main responsibility of the bank is to keep them satisfied. This study is believed to provide a mirror view into important factors such as debt equity ratio, return on shareholder's equity, earning per share, which are of a bigger concern to the shareholders. Comparison of the joint venture banks in terms of these factors provide the shareholders, creditors or any other stakeholders with an idea of the 
financial soundness and capital management of the bank as compared to others and help shape their investment decisions in those banks. Besides all banks also know their position in the management of risk factors, it is also believed that the study provides banks indirectly their effectiveness in providing services and how efficiently they have been able to collect all the charges from their customers.

Relevant literature is reviewed in second section of the article. A research methodology and research tool used is explained in third section and data analysis and interpretation is done in forth part of this article. Finally, conclusion from the research included in fifth section.

\section{The Methodology}

\subsection{Theoretical Framework}

This research is based on the assumptions on the study conducted by De Young and Rice (2004) which has used the regression model to analyze the relationship between non-interest income and financial performance of commercial banks using independent variables like service charge on deposit account, fee income from fiduciary activities, other non-interest income, market conditions, technological changes with dependent variables as ROA and ROE. These both measures help to determine the profitability.

Non-interest income (NII) is the bank's income mainly from service and penalty charges and to a much less extent from asset sales and property leasing. Unlike interest income, this income is largely unaffected by economic and financial market cycles and is usually not controlled by law or regulations. It is any income that bank earns from activities' other than their core intermediation business from their investments. Banks seek to increase non-interest income because it is considered to have traits that make it different from interest income and thus desirable. In particular, non-interest income could lead a bank to be less risky if it leads to greater diversification. It is calculated as:

$\mathrm{NII}=$ Exchange Income + Other Income + Other Operating Income + Commission and Discount

The independent variables and dependent variables of the study are presented in table 1. 
Figure 1: Conceptual Framework

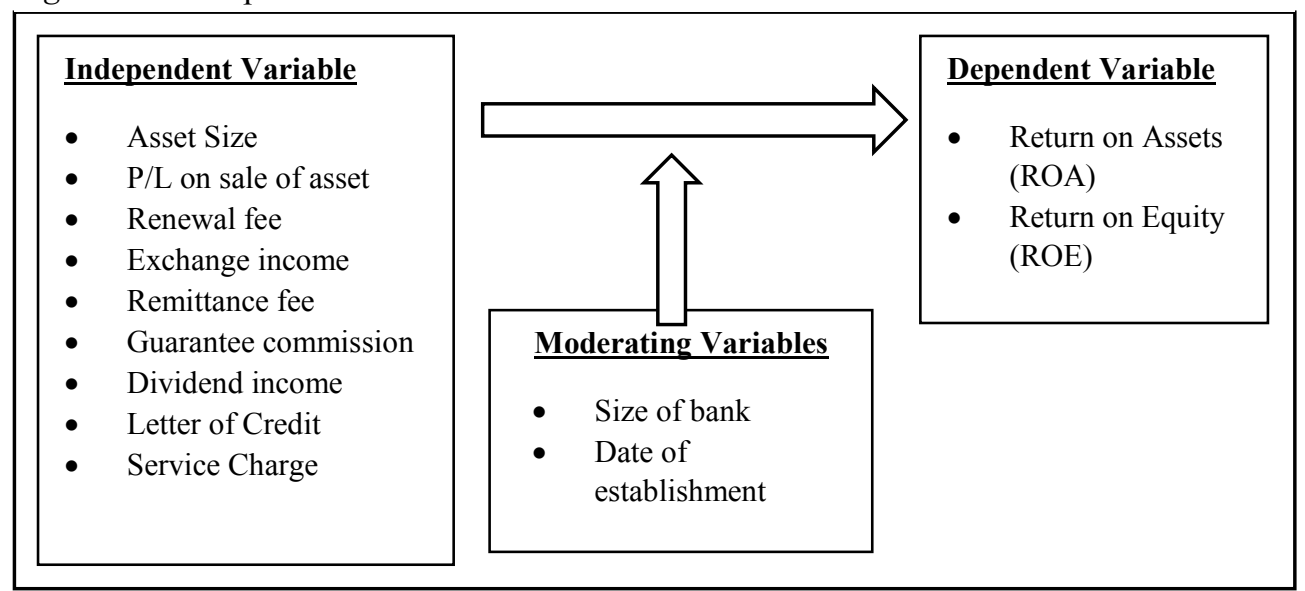

\subsection{Specification of Variables}

There are certain variables which are used during the research which are as follows:

\subsection{Dependent Variable}

Return on Asset (ROA): Return on asset is an indicator of how profitable a company is relative to its total assets. ROA gives an idea as to how efficient management is at using its assets to generate earnings. It is referred to as "return on investment". ROA tells you what earnings were generated from invested capital or assets. ROA for public companies can vary substantially and will be highly dependent on the industry. This is why when using ROA as a comparative measure, it is best to compare it against a company's previous ROA number or the ROA of a similar company. It is calculated as: $\mathrm{ROA}=($ Net Profit/Total Assets) * 100 .

Return on Equity (ROE): Return on equity is the amount of net income returned as a percentage of shareholder's equity. ROE measures a corporation's profitability by revealing how much profit a company generates with the money shareholders have invested. It is a measure of how well a company uses investment to generate earning growth. It is especially used for comparing the performance of companies in the same industry. It is expressed in percentage and calculated as: $\mathrm{ROE}=(\mathrm{Net}$ Income/ Shareholders Equity) * 100. 


\section{Independent Variables}

Profit/Loss on Sale of Assets: Profit/loss on sale of assets of commercial bank is defined as the profit or loss of land and building and assets owned by commercial bank. The assets are classified as land, vehicles, buildings, intellectual property and default loan property. The profit is earned when the market price is greater than the cost price owned and loss vice versa. A gain resulting from selling an asset at a price higher than the original purchase price. Dividend Income: Dividend income is earned from the dividend paid by company listed in Nepalese market. As per NRB directives, commercial bank can invest in insurance companies, hydropower, microfinance, hotels and other manufacturing companies' listed. Letter of Credit: Letter of credit means an instrument issued by a bank to another bank instructing to accept the check, draft, or bill of exchange drawn by specified person up to the limit of specified amount. It includes Telex or communication charges to buyers bank couriers, postage reimbursement bank charge, controllable fee and buyer's letter of credit. Guarantee Income: A contract of guarantee is a contract to perform the promise or discharge of liability of third person in case of his default. In other words, if the debtor fails to settle a debt the bank will cover it. This is the commission for the bank on the behalf of being guarantee. Bank guarantee is generally of two types: financial and performance guarantee. Remittance Fee: Remittance transaction includes a fee charged by the sending agent who is paid by the sender and a currency conversion fee for delivery of local currency to the beneficiary in recipient country. In such transaction money transfer operators require the beneficiary to pay a fee to collect remittances. This fee may be charged to account for frequent exchange rate movements. Size of the Bank: It generally covers the area and size of the business it has occupied. It mainly deals with the market size and exposure of its business in the market. It also deals with the number of employees it has employed and its share in the industry. Exchange Income: Exchange income is the income earned from purchase and sale of foreign exchange or the acts of borrowing, giving credits and of accepting or providing foreign exchange in any manner. In finance an exchange rate between two currencies is the rate at which one currency will be exchange for another. The commercial bank earns income through the fluctuation in exchange rate and book up foreign currency. Service Charge: It is a fee incurred by a company for the expenses associated with its account transaction. The term service charge covers all charges and fees made by a bank to their customers. In common parlance, the term often relates to charges in respect of loan and services it renders. These charges may take many forms including (i) Monthly charges for the provision of the account (ii) Charges for specific transactions or service processing fee (iii) Interest in respect of overdrafts and (iv) Charges for exceeding authorized overdrafts limits or making payments where no authorized overdraft exists. Renewal Fee: it 
comprises of renewal of overdraft account, loan, account renewal, insurance renewal, card renewal and other services rendered through commercial bank.

\subsection{Model Specification}

Multiple linear regression attempts to model the relationship of joint venture banks of Nepal with the internal variables of profitability.

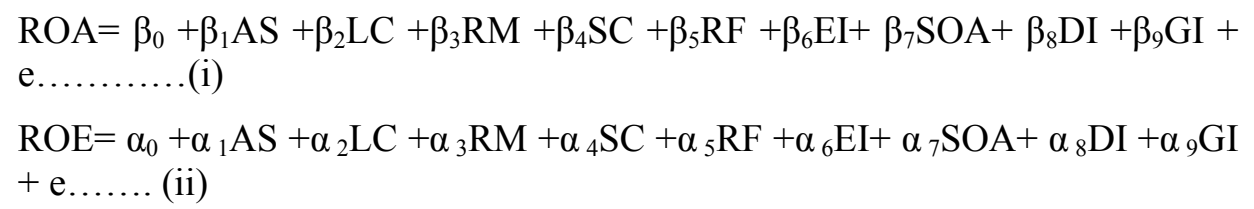

Where, $\mathrm{ROA}=$ Return on Assets, $\mathrm{ROE}=$ Return on Equity, $\mathrm{AS}=$ Asset Size, $\mathrm{LC}=$ Letter of Credit Fee, $\mathrm{RM}=$ Remittance $\mathrm{Fee}, \mathrm{RF}=$ Renewal Fee, $\mathrm{SC}=$ Service Charge, $\mathrm{EI}=$ Exchange Income, $\mathrm{SOA}=$ Profit or loss on sale of asset, $\mathrm{DI}=$ Dividend Income, $\mathrm{GI}=$ Guarantee Income, $\beta_{1}, \beta_{2} \ldots \beta_{9}$ = Coefficient of selected bank variables with ROA, $\beta_{0}=$ Regression Constant with ROA, $\alpha_{1}, \alpha_{2} \ldots \ldots \ldots \ldots ., \alpha_{9}=$ Coefficient of selected bank variables with ROE, $\alpha_{0}=$ Regression Constant with ROE and $\mathrm{e}=$ Stochastic Term.

\subsection{Research Design and Plan}

The study is confined to the joint ventures banks in the banking sector. Currently there are 7 joint venture banks in operation in Nepal with their branches located in different parts of the country. Out of the population of 7 joint venture banks, each and every joint ventures bank is selected as samples. The banks selected as to be studied for this research are Everest bank, Himalayan bank, Nepal SBI bank, Standard Charter bank, NMB bank, NABIL bank and Nepal Bangladesh bank These banks are taken into consideration as they are the joint ventures of other banks across the globe. Such banks are the banks of Africa, South Asia and Europe. Data for 10 years taken for 5 joint venture banks and data for The NBBL is taken for just 5 years because of the unavailability of the schedule part of the annual report. Also the data for NMB bank is taken for 9 years only as the initial period is went into transformation from finance company to commercial bank.

Particularly the joint venture banks are selected because in the current context with the activities like mergers going on, in order for commercial banks to meet the capital requirement of 8 billion, the joint venture banks have seemed to be well off in doing so without much of the trouble. Also selecting the joint venture would mean how they would function in the future context in regards to the increased capital requirement with relation to their profits considering there proportion of non-interest income. As there are 28 commercial banks at the moment, selecting 
the joint venture banks only will help to look at a particular segments which can help to deal with the detail study of the particular segment with ease and more focus rather than the entire " $A$ " class banks. The joint ventures are selected to know about their financial and economical soundness.

All the joint venture banks are studied and compared. The data are collected from the secondary sources such as balance sheets, profit and loss accounts from fiscal year $2005 / 6$ to $2015 / 16$. The researcher has used analytical and descriptive study methods with the help of appropriate statistical or financial tools.

The data collected is to be arranged and managed in MS Excel so that it can be further used in SPSS version 20 for analyzing the data. The data in MS excel is presented in percentage or ratio form and analyzed using various ratio, trend analysis techniques and correlation analysis.

Validity and Reliability are the two crucial factors that play a vital role throughout the study i.e., since designing of the study till examining the study. For the secondary data analysis, multi co-linearity, normality test and autocorrelation have been carried out along with cross checking of data to check the reliability and validity of data. Variance Inflation Factor (VIF) will be checked for the selected variables. The reliability of a measure indicates the stability and consistency with which the instrument is measuring the concept and helps to access the goodness of a measure.

Since the study requires to know the relationship between variables for which the hypothesis testing, ANOVA, normality test, and multiple regression analysis is done so as to derive the inferential information that will help in obtaining the outcome of the study. Tables will be used as the output of SPSS and will be analyzed as per the data that is inputted.

\section{Result and Discussion}

\subsection{Trend Analysis of the variables}

All the variables dependent (ROA and ROE) and independents (Asset Size, Letter of Credit Fee, Guarantee Income, Remittance Fee, Service Charge, Renewal Fee, Exchange Income, $\mathrm{P} / \mathrm{L}$ on sale of Assets and Dividend income) in joint venture have been continuously increasing throughout the study time period, although the rate varies from year to year. The average ROA shows steady increase for the time period taken into consideration for the study. The minimum average ROA being $1.70 \%$ on $2065 / 66$ and the maximum is $2.29 \%$ on $2069 / 70$. On the other hand, ROE average shows steady decrease for the same time period. The minimum average ROE being 18.77 on $2071 / 72$ and the maximum is 26.99 on $2063 / 64$. The trend of ROA and ROE is presented in figure (2). 
The average asset size shows that there is a steady increase in the asset size for the banks till the year 2069/70. However, the asset size is increasing rapidly beyond the point 2069/70 through 2072/73. The minimum average asset size being Rs 24.94 billion on $2063 / 64$ whereas the maximum is Rs $86.58 \mathrm{bn}$ on $2072 / 73$. Similarly, the average Letter of Credit Fee shows steady increase throughout the year taken into consideration for the study. The minimum average LC fee being Rs 22.88 million on 2063/64 and the maximum is Rs 48.39 million on 2072/73. Further, the average Guarantee Income shows steady increase till the year $2067 / 68$ and beyond this point the guarantee income for commercial banks is increasing at a rapid scale till2072/73. The minimum average guarantee income being Rs 22.99 million on 2063/64 and the maximum is Rs 123.47 million on 2072/73. On the other hand, the average Remittance Fee shows steady increase for the time period taken into consideration for the study. The minimum average remittance fee being Rs 29.70 million on 2063/64 and the maximum is Rs 56.82 million on 2072/73.

The average Service Charge shows steady increase for the time period till 2065/66 but beyond that point the service charge have increased exponentially till 2072/73 for time period taken into consideration for the study. The minimum average service charge being Rs 21.94 million on 2063/64 and the maximum is Rs147.17 million on 2072/73. Also, the average Renewal Fee shows steady increase for the time period till 2066/67 but beyond that point the service charge have increased exponentially till $2072 / 73$ for time period taken into consideration for the study. The minimum average renewal fee being Rs 25.09 million on 2063/64 and the maximum is Rs 99.91 million on 2072/73. Similarly, the average Exchange Income shows steady increase for the time period taken into consideration for the study. The minimum average exchange income being Rs 154.92 million on $2063 / 64$ and the maximum is Rs 346.94 million on 2072/73. Addition to this, the average $\mathbf{P} / \mathbf{L}$ on sale of assets shows steady increase for the time period till 2068/69 and then it decreased for a couple of years to end with Rs 13.95 million for the year 2072/73.taken into consideration for the study. The minimum average exchange income being 5.59 million on 2063/64 and the maximum is Rs 15.04 million on 2071/72. Finally, the average Dividend Income shows steady increase for the time period till $2069 / 70$ and then it increased rapidly till 2072/73. The minimum average dividend income being 0.43 million on 2063/64 and the maximum is Rs 17.70 million on 2072/73. 
Figure 2: ROE and ROA

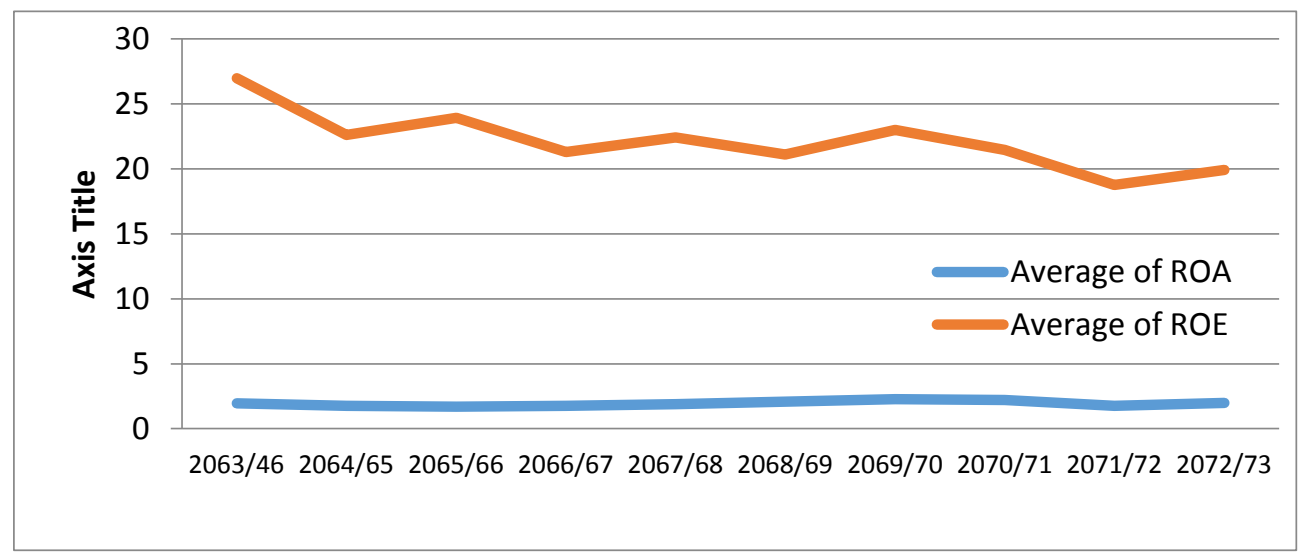

\subsection{Descriptive Statistics}

The selected variables both dependent and independent are statistically observed and described. Descriptive analysis was conducted to observe the trend of the time series data to be used in the economic analysis model of the dependent and independent variables. The table above describes about the descriptive statistics of various dependent and independent variables taken into consideration for the study. For the dependent variable like ROA and ROE, the yearly index are $1.93 \%$ and $21.97 \%$ during the period of $2063 / 64$ to $2072 / 73$ with recorded standard deviation of 0.71 and 7.45 respectively implying a medium volatility in commercial banks.

Table No. 1: Descriptive Statistics for various Variables

\begin{tabular}{lllll}
\hline Particulars & Minimum & Maximum & Mean & Std. Deviation \\
\hline Asset Size & $8,927,891,620$ & $127,300,195,373$ & $49,395,789,053$ & $26,079,987,176$ \\
Letter of Credit Fee & 15,350 & $95,666,333$ & $32,790,982$ & $20,660,280$ \\
Guarantee Income & 201,045 & $376,977,047$ & $61,727,728$ & $66,260,915$ \\
Remittance Fee & 34,854 & $118,624,131$ & $44,965,792$ & $29,924,338$ \\
Service Charge & $3,775,076$ & $249,657,714$ & $69,731,593$ & $59,457,767$ \\
Renewal Fee & 46,100 & $357,768,880$ & $70,285,431$ & $76,462,130$ \\
Exchange Income & 97,130 & $629,560,698$ & $227,244,624$ & $179,937,310$ \\
P/L of sale of asset & 151,687 & $55,747,081$ & $9,902,680$ & $12,231,888$ \\
Dividend Income & 148,200 & $61,968,612$ & $6,599,733$ & $10,662,924$ \\
Return on Asset & 0.28 & 4.01 & 1.93 & 0.71 \\
Return on Equity & 2.31 & 39.63 & 21.97 & 7.45 \\
\hline
\end{tabular}

The mean of asset size records 8927.89(in millions), letter of credit fee Rs 32.79(in millions), guarantee income Rs 61.73(in million), remittance fee Rs 44.97(in million), service charge Rs 69.73(in million), renewal fee Rs 70.29(in million), exchange income Rs 227.24(in million), $\mathrm{P} / \mathrm{L}$ on sale of asset Rs 9.90(in million), and 
dividend income Rs 6.6(in million). The result reveals that most of the high concentration on mean of joint venture banks is on exchange income, renewal fee, service charge, remittance fee, guarantee income and letter of credit fee. Although the mean value for exchange income is highest but the standard deviation of Rs 179.94(in million) makes less reliable for the category of non-interest income.

\subsection{Correlational Analysis}

Correlational Analysis is the process of studying the strength of that relationship with the available statistical data. The sample correlational coefficient ranges between -1 and +1 and quantifies the direction and strength of the linear association between the two variables. The correlation between the two variables can be positive (i.e. higher level of one variable are associated with higher levels of the other) or negative (i.e., higher level of one variable are associated with lower levels of the other). Correlation analysis contributes to the understanding of economic behavior, aids in locating the critically important variable on which other depend. The effect of correlation is to reduce the range of uncertainty. The prediction based on correlational analysis is likely to be more variable and near to reality.

Table No. 2: Correlations among Variables

\begin{tabular}{llllllllllll}
\hline & $\mathrm{X} 1$ & $\mathrm{X} 2$ & $\mathrm{X} 3$ & $\mathrm{X} 4$ & $\mathrm{X} 5$ & $\mathrm{X} 6$ & $\mathrm{X} 7$ & $\mathrm{X} 8$ & $\mathrm{X} 9$ & $\mathrm{X} 10$ & $\mathrm{X} 11$ \\
\hline $\mathrm{X} 1$ & 1 & $.8^{* *}$ & 0.171 & $.752^{* *}$ & $.715^{* *}$ & $.658^{* *}$ & $.566^{* *}$ & -0.119 & $.721^{* *}$ & 0.135 & 0.174 \\
$\mathrm{X} 2$ & & 1 & 0.171 & $.723^{* *}$ & $.610^{* *}$ & $.618^{* *}$ & $.552^{* *}$ & -0.173 & $.772^{* *}$ & $.302^{*}$ & $.314^{*}$ \\
$\mathrm{X} 3$ & & & 1 & -0.104 & 0.18 & 0.07 & 0.17 & $.446^{* *}$ & 0.072 & $.404^{* *}$ & 0.035 \\
$\mathrm{X} 4$ & & & & 1 & $.401^{* *}$ & $.773^{* *}$ & $.557^{* *}$ & $-.280^{*}$ & $.530^{* *}$ & 0.165 & $.358^{* *}$ \\
X5 & & & & & 1 & $.340^{* *}$ & 0.071 & -0.182 & $.560^{* *}$ & 0.112 & 0.033 \\
X6 & & & & & & 1 & $.481^{* *}$ & -0.125 & $.488^{* *}$ & 0.086 & 0.12 \\
X7 & & & & & & 1 & 0.09 & $.601^{* *}$ & $.422^{* *}$ & $.469^{* *}$ \\
X8 & & & & & & & 1 & -0.129 & $.259^{*}$ & -0.012 \\
X9 & & & & & & & & 1 & 0.123 & 0.087 \\
X10 & & & & & & & & & 1 & $.784^{* *}$ \\
X11 & & & & & & & & & & 1 \\
\hline
\end{tabular}

Note: ${ }^{* *}$ means significance at 0.01 (two tailed); ${ }^{*}$ means significance at 0.05 (two tailed)

Where, X1=Assets Size, X2= Letter of Credit Fee, X3= Guarantee Income, X4= Remittance Fee, X5 = Service Charge, X6= Renewal Fee, X7= Exchange Income, $\mathrm{X} 8=$ Profit/loss on Sale of Assets, X9= Dividend Income, X10= Return on Assets (ROA), X11= Return on Equity (ROE)

For the case or ROA, the result reveals that the corresponding coefficient value as given in the table no. 2 indicates that there is positive relationship among all the variable implying in ROA. Further, among the variables, 4 of them named ROA and letter of credit fee, ROA and guarantee income, ROA and exchange income and ROA and Profit/Loss on sale of asset are statistically significant correlation between ROA. This means increase in one of the mentioned variable will significantly increase the value of other variables and vice versa. Rest variables are not statistically significant indicates the correlation relation cannot be predicted 
from the values appeared in the result table. Similar to ROA, ROE also revealed the corresponding coefficient value. From the table no 2 it is clear that only one variable has negative relationship in ROE. However, only 3 of the variables i.e. $\mathrm{ROE}$ and letter of credit fee, ROE and remittance fee and ROE and exchange income are statistically significant correlation with ROE. The correlation table indicates that in both ROA and ROE, there is positive relationship between variables and indicates increase in one variable help to improve another variables and vice versa.

\subsection{Multiple Regression Analysis}

In order to test the statistical significance and robustness of the results, regression models have been used. The regression analysis has been conducted to investigate whether or not the return on assets and return on equity are affected by the bank specific internal non-interest variables.

The table 4.3 shows that there is significant relationship of ROA with assets size, letter of credit fee, guarantee income, service charge, exchange income and dividend income and there is no significant relationship with remittance fee, renewal fee and profit/loss on sale of assets. The significant relationship indicates that the variables like assets size, letter of credit fee, guarantee income, service charge, exchange income and dividend income will affect the dependent variable like ROA such that an increase in value in these variables will increase the value of the return on assets and vice versa. The end result is that the null hypothesis $\mathrm{Ho}_{1}$, $\mathrm{Ho}_{2}, \mathrm{Ho}_{3}, \mathrm{Ho}_{5}, \mathrm{Ho}_{7}$, and $\mathrm{Ho}_{9}$ are rejected. The null hypothesis $\mathrm{Ho}_{4}, \mathrm{Ho}_{6}$ and $\mathrm{Ho}_{8}$ are accepted as they have significance value greater than 0.05 .

Table No. 3: Multivariate Regression Analysis with VIF on ROA and ROE

\begin{tabular}{lcccccc}
\hline & \multicolumn{3}{c}{ Analysis with VIF on ROA } & \multicolumn{3}{c}{ Analysis with VIF on ROE } \\
\hline Particulars & $\begin{array}{c}\text { Standardized } \\
\text { Coeff. (Beta) }\end{array}$ & Sig. & VIF & $\begin{array}{c}\text { Standardized } \\
\text { Coeff. (Beta) }\end{array}$ & Sig. & VIF \\
\hline (Constant) & 1.172 & 0 & - & 14.002 & 0 & \\
Asset Size & -0.89 & 0.001 & 6.9 & -0.684 & 0.008 & 6.9 \\
Letter of Credit Fee & 0.479 & 0.021 & 4.64 & 0.498 & 0.018 & 4.64 \\
Guarantee Income & 0.236 & 0.059 & 1.713 & -0.058 & 0.641 & 1.713 \\
Remittance Fee & 0.27 & 0.217 & 5.358 & 0.454 & 0.043 & 5.358 \\
Service Charge & 0.6 & 0.002 & 4.029 & 0.472 & 0.016 & 4.029 \\
Renewal Fee & -0.183 & 0.242 & 2.745 & -0.335 & 0.037 & 2.745 \\
Exchange Income & 0.778 & 0 & 3.301 & 0.857 & 0 & 3.301 \\
Profit and loss of sale of asset & 0.164 & 0.154 & 1.48 & 0.028 & 0.808 & 1.48 \\
Dividend Income & -0.46 & 0.014 & 3.768 & -0.654 & 0.001 & 3.768 \\
R & & 0.728 & & & 0.720 & \\
R Square & & 0.53 & & & 0.519 & 0.439 \\
Adjusted R Square & & 0.452 & & & 5.58396 & \\
Std. Error of Estimate & & 0.52431 & & & 1.053 & \\
Durbin-Watson & 1.076 & & & & \\
\hline
\end{tabular}




\section{Analysis of Factors Affecting ROA}

Also before the analysis of the data, we should detect if there is any multicollinearity among the variable chosen. The variance inflation is performed to support the validity of the regression results. In case of VIF, if the results are below 10 , it suggests that there is no multi-collinearity. The result of VIF reveals that it is reasonably good. The values of variance inflation factor for the variables are in the range from 1.48 to 6.9 for variables assets size, letter of credit fee, guarantee income, remittance fee, service charge, renewal fee, exchange income, profit/loss on sale of assets and dividend income.

The beta for asset size -0.89 signifies that for Rs 1 increase in asset size will lead to decrease the ROA by $0.89 \%$. the beta of letter of credit fee, guarantee income, remittance fee, service charge, exchange income, and profit/loss on sale of assets signifies that Rs 1 increase in these variables will lead to increase ROA by $0.479 \%$, $0.2336 \%, 0.27 \%, 0.6 \%, 0.778 \%$ and $0.164 \%$ respectively. Whereas the beta of -0.183 and -0.46 for renewal fee and dividend income will cause to reduce the ROA by $0.183 \%$ and $0.46 \%$ respectively for every Rs 1 increase in the variables.

The above table describes the summary of regression analysis with regards to the dependent variable return on assets. The value of $\mathrm{R}^{2}=0.53$ means that the selected bank variable will explain only $53 \%$ of the change in ROA whereas the rest $47 \%$ is accounted to other variables. The study used Durbin-Watson test to determine the auto correlation of all variables. The study confines that there is no auto correlation in Nepalese commercial bank and selected bank internal variables since the value is near to 2 .

\section{Analysis of Factors Affecting ROE}

In Model 2, we have analyzed the relationship between the dependent variable ROE with independent variables such as Assets size, letter of credit fee, guarantee income, remittance fee, service charge, renewal fee, exchange income, profit/loss on sale of assets and dividend income during the period of ten years.

The table 3 shows that there is significant relationship of ROE with independent variables like asset size, letter of credit fee, remittance fee, service charge, renewal fee, exchange income and dividend income and there is no significant relationship of profit/loss on sale of assets and guarantee income with ROE. The significant relationship indicates that the variables like assets size, letter of credit fee, service charge, exchange income, renewal fee and dividend income will affect the dependent variable like ROE such that an increase in value in these variables will increase the value of the return on equity and vice versa. 
Also before the analysis of the data, we should detect if there is any multicollinearity among the variable chosen. The variance inflation is performed to support the validity of the regression results. In case of VIF, if the results are below 10 , it suggests that there is no multi-collinearity. The result of VIF reveals that it is reasonably good. The values of variance inflation factor for the variables are in the range from 1.48 to 6.9 for variables assets size, letter of credit fee, guarantee income, remittance fee, service charge, renewal fee, exchange income, profit/loss on sale of assets and dividend income. The end result is that the null hypothesis $\mathrm{Ho}_{1}, \mathrm{Ho}_{2}, \mathrm{Ho}_{4}, \mathrm{Ho}_{5}, \mathrm{Ho}_{6}, \mathrm{Ho}_{7}$, and $\mathrm{Ho}_{9}$ are rejected. The null hypothesis $\mathrm{Ho}_{3}$ and $\mathrm{Ho}_{8}$ are accepted as they have significance value greater than 0.05 .

The beta for asset size -0.684 signifies that for Rs 1 increase in asset size will lead to decrease the ROE by $0.684 \%$. the beta of letter of credit fee, remittance fee, service charge, exchange income, and profit/loss on sale of assets signifies that Rs 1 increase in these variables will lead to increase ROE by $0.498 \%$, $0.454 \%, 0.472 \%, 0.857 \%$, and $0.028 \%$ respectively. Whereas the beta of -0.058 , 0.335 and -0.654 for guarantee income, renewal fee and dividend income will cause to reduce the ROE by $0.058 \%, 0.335$ and $0.654 \%$ respectively for every Rs 1 increase in the variables.

The table describes the summary of regression analysis with regards to the dependent variable return on equity. The value of $\mathrm{R}^{2}=0.519$ means that the selected bank variable will explain only $51.9 \%$ of the change in ROE whereas the rest $48.1 \%$ is accounted to other variables. The study used Durbin-Watson test to determine the auto correlation of all variables. The study confines that there is no auto correlation in Nepalese joint venture commercial bank and selected bank internal variables since the value is near to 2 .

\section{Variance Analysis with ANOVA on ROA and ROE}

It is a collection of statistical models, the difference among group means and their associated procedures used as variation among and between groups. A variety of techniques are used with multiple factor ANOVA to reduce cost. Our techniques used in factorial designs are to minimize replication and to combine groups when effects are found to be statistically or practically insignificant. An experiment with many insignificant factors may collapse into one with a few factors supported by many replications.

Table No 4.ANOVA on ROA and ROE

\begin{tabular}{llllll}
\hline & Sum of Squares & Df & Mean Square & F & Sig. \\
\hline Regression & 16.73 & $\mathbf{9}$ & 1.859 & 6.762 & .000 \\
Residual & 14.845 & 54 & 0.275 & & \\
Total & 31.575 & 63 & & & \\
\hline
\end{tabular}


The table 4 describes the output of the ANOVA analysis and whether we have a statistically significant difference between group means. The data reveals that the significance level is 0.000 which is less than 0.05 concluding that there is a significant difference in the mean of the selected bank internal variables with return on assets. The table 4 describes the output of the ANOVA analysis and whether we have a statistically significant difference between group means. The data reveals that the significance level is 0.000 which is less than 0.05 concluding that there is a significant difference in the mean of the selected bank internal variables with return on equity.

Table No.5: ANOVA on ROA and ROE

\begin{tabular}{llllll}
\hline & Sum of Squares & df & Mean Square & F & Sig. \\
\hline Regression & 1814.765 & 9 & 201.641 & 6.467 & .000 \\
Residual & 1683.751 & 54 & 31.181 & & \\
Total & 3498.517 & 63 & & & \\
\hline
\end{tabular}

\section{Concluding Remarks}

The research was conducted to identify the non-interest income variables that will likely affect the financial performance of the joint venture banks of Nepal. To measure the financial performance, the indicator of profitability i.e. returns on assets and return on equity is taken into consideration for the study. We find out the non-interest income variables that would affect the financial performance of the joint venture banks. The variables are assets size, letter of credit fee, guarantee income, remittance fee, dividend income, exchange income, service charge, and renewal fee. Through this it can be concluded that banks need to keep the noninterest income variables into consideration at times for improving the financial performance of the joint venture banks. As apart from the interest income, there are lot of non-interest variables which leads to profitability so the banks looking to increase its profitability with lesser risk need to take these variables into consideration.

In order to identify the relationship of these non-interest income variables on the indicators of financial performance that is return on assets and return on equity, it is found that not all variables have equal effect on the profitability as measure of financial performance. It is noted that for joint ventures the factors like assets size, letter of credit fee, guarantee income, remittance fee, dividend income, exchange income, service charge, and renewal fee have a significant relationship with the measure of financial performance that is return on assets and return on equity. Therefore, banking institutions can focus on these variables to enhance their performance.

To know about the impact of these non-interest variables on the financial performance, it is found that the variables like letter of credit fee, service charge, 
exchange income and dividend income leads to increase both the return on assets and return on equity. Hence, the banks instead of focusing on all the other variables of non-interest income, they can scrutinize there area of focus on these four variables more than the other as they have a significant relationship on the profitability. Further, the parameter of non-interest income amounts to almost 50\% effect on the profitability. Hence these variables should not be ignored as they lead to increase in profit with minor risk than the interest income variables.

The findings provide an insight into the characteristics and practices of successful commercial in terms of profitability. In the view of these, the following recommendations can be made which may be useful for bank management, policy makers, shareholders and further researchers.

- The banks management should review at regular times about the inclusion of the non-interest variables and its inclusion on the profitability. As the non-interest variables amounts to fifty percent effect on the profitability, hence they should try to enhance income in these variables to assure more profits.

- The finding of the research can help the policy makers to know about how they must work in the future that is in best interest for the banking institutions. With the result of this research paper they can develop policy that will more likely cause to increase the profitability in these variables by introducing new products to customers.

- As for shareholders, while evaluating the profitability of the banking institutions, they must also consider the contribution of the non-interest income apart from the interest income sources. With the non-interest income causing almost fifty percent impacts on profitability, they must consider this information to know which bank is performing well in the market as oppose to others.

- This research paper becomes a guiding principle for the future research works in this particular field. The further researcher can also add up other variables while analyzing the profitability which couldn't be incorporated in this paper. 


\section{References}

Craigwell, R., \& Maxwell, C. (2005).Non-interest income and financial performance at commercial banks in Barbados. Seminar paper presented on 26th Annual Review Seminarto Research Department, Central Bank of Barbados.

De Young, R., \&Rice, T. (2004). Non-interest income and financial performance at U.S. commercial banks. The Journal Financial Review, 39(1), 10-18.

Feldman, R. J., \& Schmidt, J. (1999). Noninterest income: A potential for profits, risk reduction and some exaggerated claims. Fedgazette, 20-21.

Gichure, K. S. (2015). The relationship between non-interest income and financial performance of commercial banks in Kenya. International Journal of Finance and Accounting, 1(2), 35-47.

Guo, R. (2015). Cross-border management: Theory, method and application. Springer.

Hoang Thi Linh, C. (2014). How did revenue diversification affect bank performance in emerging economies during the financial crisis? [Unpublished Master's thesis]. University of Vaasa.

Kallianiotis, I. (2013). International financial transactions and exchange rates: Trade, investment, and parities. Springer.

Lozano-Vivas, A., \& Pasiouras, F. (2010). The impact of non-traditional activities on the estimation of bank efficiency: international evidence. Journal of Banking \& Finance, 34(7), 1436-1449.

Morris, C. S., \& Regehr, K. (2014). What explains low net interest income at community banks?. Economic Review, 2, 5-33.

Nepal, S. (2015). Impact of non-interest income on profitability of commercial Banksin Nepal [UnpublishedMBA Research Project].Ace Institute of Management, Pokhara University.

Nichols, H. W. (1950). Joint ventures. Virginia Law Review, 425-459.

Rai, R., Kharel, S., Devkota, N., \& Paudel, U. R.(n.d.). Customers perception on green banking practices: A desk. The Journal of Economic Concerns, 10(1), 82-95.

Raluca, D. S. O. (2012). Globalization and its effects on the banking management. Annals-Economy Series, 4, 133-136. 
Saunders, A. (2014). Financial markets and institutions. McGraw-Hill Higher Education.

Sherene, A., \& Tapper, B. (2010). Non-interest income, financial performance \& the macro economy: Evidence on Jamaican panel data (Vol. 4). Working paper, series.

Timsina, S. (2015). Capital structure management of joint venture banks of Nepal. Journal of Business and Social Sciences Research, 1(1), 58-79. 